\title{
Second Times Picogram per Milliliter
}

National Cancer Institute

\section{Source}

National Cancer Institute. Second Times Picogram per Milliliter. NCI Thesaurus. Code C85812.

Seconds times picograms per milliliter. 